\title{
PENGARUH ASAL BAHAN STEK DAN JENIS ZAT PENGATUR TUMBUH (ZPT) PADA PERTUMBUHAN STEK DAUN LIDAH MERTUA (Sansevieria trifasciata)
}

\section{(The Effects of Origin of Cuttings and Various Plant Growth Regulators (PGR) Treatment on the Growth of Plant Leaf Cuttings Sansevieria trifasciata)}

\section{Pienyani Rosawanti}

\author{
Program Studi Agroteknologi Fakultas Pertanian dan Kehutanan Universitas Muhammadiyah Palangkaraya \\ Jl. RTA Milono Km.1,5 Palangka Raya, Kalimantan Tengah \\ e-mail : pienyani@yahoo.com
}

\begin{abstract}
This research aims to study the growth response of plant leaf cuttings mother in-law's tongue (Sansevieria parva) origin of cuttings and various plant growth regulator treatment. Research was using complete randomized block design (RAKL) with 6 replications. The first factor was the origin of cuttings, i.e. the top/tip leaves, the middle leave, and the bottom/leaves base. The second factor was the various plant growth regulator (PGR) treatment i.e. onion extracts, water coconut and Rootone-F. Parameters observed and measured is the experiment root length, number of roots, root wet weight and root dry weight. The results showed that plant growth regulator treatment significant effect on root length, number of roots, root wet weight, and root dry weight. The treatment combination of origin of cuttings and synthetic plant growth regulator by cutting material from the middle to give the best results on the number of root and root wet weight.
\end{abstract}

Keywords : leaf cuttings growth, Sansevieria trifasciata, plant growth regulator, the origin of cuttings

\begin{abstract}
Abstrak
Penelitian ini bertujuan untuk mempelajari respon pertumbuhan stek daun tanaman lidah mertua (Sansevieria trifasciata) terhadap berbagai perlakuan asal bahan stek dan zat pengatur tumbuh (ZPT). Penelitian menggunakan Rancangan Acak Kelompok Lengkap (RAKL) dengan enam ulangan Faktor I adalah asal bahan stek, yaitu bagian atas/ujung daun bagian tengah daun dan bagian bawah/pangkal daun. Faktor II adalah jenis zat pengatur tumbuh (ZPT) yaitu ekstrak bawang merah, air kelapa dan Rootone-F. Parameter yang diamati dan diukur adalah panjang akar, jumlah akar, bobot basah akar dan bobot kering akar. Hasil penelitian menunjukkan bahwa asal bahan stek berpengaruh terhadap panjang akar, jumlah akar, bobot basah akar dan bobot kering akar. Perlakuan jenis Zat Pengatur Tumbuh (ZPT) berpengaruh terhadap peubah panjang akar, jumlah akar, bobot basah akar dan bobot kering akar. Perlakuan kombinasi asal bahan stek bagian tengah dengan Rootone-F memberikan hasil yang terbaik pada jumlah akar dan bobot basah akar stek.
\end{abstract}

Kata kunci : asal bahan stek, lidah mertua, pertumbuhan stek daun, zat pengatur tumbuh

\section{PENDAHULUAN}

Tanaman lidah mertua (Sansevieria trifasciata) merupakan tanaman hias yang banyak memiliki manfaat. Selain sebagai tanaman hias, lidah mertua juga memiliki manfaat dalam menjaga lingkungan dan kesehatan. Hasil kajiian yang dilakukan oleh
NASA (National Aeronautics and Space Administration) Amerika Serikat (1989) menunjukkan bahwa Sansevieria mampu menyerap unsur polutan berbahaya yang ada di udara. Tanaman lidah mertua merupakan tanaman yang memiliki kemampuan terbesar dalam penurunan konsentrasi gas karbon 
monoksida dibandingkan dengan tanaman lili paris dan sirih gading (Adita dkk., 2011). Tanaman lidah mertua juga mengandung senyawa saponin, fenol, dan flavonoid yang berfungsi sebagai antimikroba (Lombogia et al., 2016).

Perbanyakan tanaman lidah mertua dapat dilakukan secara generatif melalui biji dan vegetatif dengan pemotongan anakan atau tunas, stek daun, stek pucuk, stek rimpang dan kultur jaringan. Perbanyakan tanaman dengan menggunakan stek daun lebih menguntungkan karena dapat menghemat bahan stek karena dapat menggunakan potongan-potongan daun dan dapat menghemat waktu karena dalam waktu singkat dapat menghasilkan stek dalam jumlah banyak (Sulistiana, 2013). Stek daun lidah mertua dapat dibagi menjadi 3 bagian yaitu bagian atas/ujung, tengah dan bawah/pangkal daun.

Salah satu cara untuk merangsang pertumbuhan stek adalah dengan pemberian zat pengatur tumbuh. Zat pengatur tumbuh atau hormon tumbuhan adalah sekumpulan senyawa organik yang terbentuk secara alami maupun dibuat oleh manusia, yang dalam konsentrasi sangat rendah mampu mempengaruh proses fisiologi tanaman seperti mendorong, menghambat, atau mengubah pertumbuhan, perkembangan, dan pergerakan (taksis) tumbuhan (Davies, 2010; Taiz dan Zeiger, 2002). Ada lima jenis hormon pada tumbuhan yaitu auksin, giberelin, sitokinin, etilen, dan asam absisat (Kende dan Zeevaart, 1997). Pemberian zat pengatur tumbuh eksogen dapat diberikan untuk mempercepat pertumbuhan akar pada stek daun. Bawang merah, air kelapa dan Rootone-F dapat digunakan sebagai zat pengatur tumbuh eksogen yang dapat merangsang pertumbuhan stek.

$\begin{array}{cccc}\text { Penelitian } & \text { Alam } & \text { et al. } & \text { (2004) } \\ \text { menunjukkan } & \text { bahwa } & \text { bawang } & \text { merah }\end{array}$
mengandung hormon auksin dan sitokinin (IAA, NAA, 2,4 D dan BAP). Penggunaan bawang merah sebagai zat pengatur tumbuh telah dilakukan terhadap berbagai jenis stek tanaman seperti pada stek melati (Marfirani dkk., 2014), stek bibit tin (Marfaung dan Hutabarat, 2015) dan stek jambu biji (Mayasari dkk., 2012). Air kelapa mengandung senyawa anorganik, vitamin, lemak, asam amino, asam organik, enzim, hormon auksin, gibberelin dan sitokinin (Yong et.al, 2009). Penggunaan air kelapa sebagai zat pengatur tumbuh telah dilakukan terhadap berbagai jenis stek tanaman seperti pada stek bibit tin (Marfaung dan Hutabarat, 2015) dan stek pucuk Meranti tembaga (Djamhuri, 2011). Rootone-F merupakan zat pengatur tumbuh sintetis yang mengandung auksin. Penggunaan Rootone-F sebagai zat pengatur tumbuh telah dilakukan terhadap Sansievera (Sulistiana, 2013) dan berbagai jenis tanaman lain seperti stek bibit tin (Marfaung dan Hutabarat, 2015).

Tujuan penelitian ini adalah untuk mempelajari respon pertumbuhan stek daun tanaman lidah mertua (Sansevieria trifasciata) terhadap berbagai perlakuan asal bahan stek dan zat pengatur tumbuh (ZPT). 


\section{METODOLOGI}

Bahan yang digunakan adalah tanaman lidah mertua (umur dua tahun), bawang merah, air kelapa, Rootone-F, tanah, pasir, pupuk kandang sedangkan alat yang digunakan adalah cutter, polibag, meteran, timbangan analitik dan oven. Penelitian dilaksanakan mulai bulan Juli sampai September 2016 di Kelurahan Panarung, Kota Palangkaraya, Kalimantan Tengah. Percobaan menggunakan Rancangan Acak Kelompok Lengkap (RAKL) yang disusun secara faktorial dengan 2 faktor. Faktor pertama adalah tiga (3) asal bahan stek daun yaitu daun bagian ujung/atas, daun bagian tengah dan daun bagian bawah/pangkal. Faktor kedua adalah tiga (3) jenis zat pengatur tumbuh yaitu sari bawang merah $100 \%$, air kelapa 100\% dan Rootone-F 100 ppm. Perlakuan diulang sebanyak enam kali. Masing-masing perlakuan terdiri atas 2 stek.

Persiapan stek dilakukan dengan menyiapkan tanaman lidah mertua yang telah berumur 2 tahun sebagai bahan stek yang berasal dari ujung, tengah dan pangkal dengan membagi panjang stek menjadi tiga bagian. Kemudian stek dipotong sepanjang $10 \mathrm{~cm}$.

Pembuatan larutan zat perangsang tumbuh (ZPT) dilakukan dengan prosedur yaitu larutan perangsang tumbuh dibuat berbahan alami, diantaranya larutan sari bawang merah 100\% (100 ml sari bawang merah air kelapa 100\% (100 ml air kelapa) dan 100 ppm larutan Rootone-F. Sari bawang merah diperoleh dengan cara menghaluskan bawang merah dan diperas sarinya (dijadikan larutan stok dengan konsentrasi 100\%).

Stek daun lidah mertua yang telah dipotong menjadi tiga bagian kemudian diberi ZPT dengan cara mengolesi bagian stek yang dipotong sesuai perlakuan. Stek yang sudah diolesi dikeringanginkan selama 2 jam agar luka bekas potongan mengering. Bahan stek yang telah diberi perlakuan ZPT ditanam dalam media sedalam $3 \mathrm{~cm}$. Setiap polybag berisi 2 bahan stek. Setek ditanam dalam polibag dengan campuran media tanah:pasir:pupuk kandang dengan perbandingan 2:1:1. Pemeliharaan bibit berupa penyiraman (2 hari sekali) dan sanitasi pot dan media tanam dilakukan dengan membersihkan gulma.

Pengamatan (dilakukan pada umur 35 HST) meliputi : 1). panjang akar (cm), diukur dari pangkal akar sampai ujung akar dengan cara meluruskan akar yang bergulung, 2). jumlah akar, menghitung semua jumlah akar yang tumbuh pada stek, 3). bobot basah akar (g), yaitu akar dipisahkan dari tajuknya kemudian dicuci sampai bersih dan diriskan lalu ditimbang dengan timbangan analitik, dan 4). bobot kering akar (g), yaitu akar dipisahkan dari stek kemudian dicuci sampai bersih dan dimasukkan ke dalam oven dengan suhu $70^{\circ} \mathrm{C}$ selama 24 jam sampai beratnya konstan, lalu ditimbang dengan timbangan analitik.

Analisis data dilakukan dengan analisis ragam, apabila berpengaruh nyata akan dilakukan analisis lanjutan dengan uji jarak berganda atau DMRT (Duncan Multiple Range Test) pada taraf 5\%. 


\section{HASIL DAN PEMBAHASAN}

Hasil analisis sidik ragam menunjukkan bahwa asal bahan stek berpengaruh terhadap panjang akar, jumlah akar, bobot basah akar dan bobot kering akar. Perlakuan jenis Zat Pengatur Tumbuh (ZPT) berpengaruh terhadap peubah panjang akar, jumlah akar, bobot basah akar dan bobot kering akar. Interaksi terdapat pada peubah jumlah akar dan bobot kering akar (Tabel 1).

\section{Panjang Akar dan Jumlah Akar}

Tabel 2 terlihat bahwa asal bahan stek bagian atas memiliki akar terpanjang yaitu sebesar $3.52 \mathrm{~cm}$ dan tidak berbeda nyata dengan asal bahan stek bagian tengah sedangkan jumlah akar terbanyak terdapat pada asal bahan stek bagian tengah dengan jumlah akar sebanyak 29.72 dan tidak berbeda nyata dengan asal bahan stek bagian atas.

Tabel 3 terlihat bahwa pemberian ZPT Rootone-F menghasilkan panjang akar tertinggi dan jumlah akar terbanyak. Pemberian ZPT Rootone-F menghasilkan panjang akar tertinggi yaitu $3.63 \mathrm{~cm}$, tidak berbeda nyata dengan ZPT bawang merah tetapi berbeda nyata dengan ZPT air kelapa. Jumlah akar terbanyak yaitu 26.17, tidak berbeda nyata dengan ZPT bawang merah tetapi berbeda nyata dengan ZPT air kelapa. Akar merupakan organ penting pada tanaman terutama untuk menyerap air dan unsur hara pada media tanam. Pemberian filtrat bawang merah dan Rootone-F dapat meningkatkan panjang dan jumlah akar stek melati (Marfirani, 2014). Pada tanaman Sansievera, perlakuan ZPT sintetik (Rootone-F) memberikan hasil yang terbaik pada parameter panjang akar (Sulistiana, 2013).

Tabel 4 terlihat bahwa asal bahan stek bagian tengah dengan pemberian ZPT RootoneF memberikan jumlah akar terbanyak yaitu 43.17, tidak berbeda nyata dengan asal bahan stek bagian atas dan berbeda nyata dengan asal bahan stek bawah. Jumlah akar pada asal bahan stek bagian tengah dengan pemberian ZPT Rootone-F berbeda nyata dengan pemberian ZPT bawang merah dan air kelapa. Perlakuan jenis ZPT pada asal stek bagian atas tidak berbeda nyata. Gambar 1 terlihat jumlah akar stek daun bagian atas tidak berbeda nyata antara ZPT bawang merah, air kelapa dan Rootone-F sedangkan pada Gambar 2 terlihat jumlah akar yang lebih banyak pada stek bagian tengah dengan pemberian ZPT Rootone-F. Bawang merah merupakan hormon eksogen yang mengandung hormon auksin yang berfungsi untuk merangsang pertumbuhan akar. Auxin dapat merangsang pembentukan akar terutama pada perbanyakan tanaman dengan menggunakan stek (Taiz dan Zeiger, 2002). Rootone-F merupakan zat pengatur tumbuh sintetik yang mengandung hormon auksin, gibberelin dan sitokinin. Pada penelitian Sulistiana (2013), perlakuan kombinasi ZPT sintetik (Rootone-F) dengan asal bahan stek bagian tengah memberikan hasil yang terbaik pada parameter panjang akar dan jumlah akar stek daun tanaman Sansevieria parva. 
Tabel 1. Rekapitulasi sidik ragam peubah asal bahan stek lidah mertua terhadap perlakuan jenis Zat Pengatur Tumbuh (ZPT) pada akhir percobaan

\begin{tabular}{lccc}
\hline \multicolumn{1}{c}{ Peubah } & Asal Bahan Stek (S) & $\begin{array}{c}\text { Jenis Zat Pengatur } \\
\text { Tumbuh/ZPT }(\mathbf{Z})\end{array}$ & Interaksi (SXZ) \\
\hline Panjang Akar $(\mathrm{cm})$ & $* *$ & $*$ & tn \\
Jumlah Akar $(\mathrm{cm})$ & $*$ & $*$ & $* *$ \\
Bobot Basah Akar $(\mathrm{g})$ & $*$ & $*$ & $*$ \\
Bobot Kering Akar $(\mathrm{g})$ & $*$ & $*$ & $\mathrm{tn}$ \\
\hline
\end{tabular}

Keterangan : tn : tidak berbeda nyata pada taraf $5 \%, * *$ : berbeda nyata pada taraf $5 \%, *$ : berbeda nyata pada $\operatorname{taraf} 1 \%$.

Tabel 2. Pengaruh asal bahan stek terhadap peubah panjang akar dan jumlah akar

\begin{tabular}{|c|c|c|}
\hline \multirow{2}{*}{ Asal Bahan Stek } & \multicolumn{2}{|c|}{ Peubah } \\
\hline & Panjang akar (cm) & Jumlah Akar \\
\hline Bagian Atas & $3.52 \mathrm{a}$ & $24.50 \quad \mathrm{a}$ \\
\hline Bagian Tengah & $3.36 \mathrm{a}$ & $29.72 \quad \mathrm{a}$ \\
\hline Bagian Bawah & $2.68 \mathrm{~b}$ & 8.89 b \\
\hline
\end{tabular}

Keterangan : Angka-angka yang diikuti oleh huruf yang sama pada kolom yang sama, tidak berbeda nyata pada taraf uji $5 \%$ (DMRT).

Tabel 3. Pengaruh Zat Pengatur Tumbuh (ZPT) terhadap peubah panjang akar dan jumlah akar

\begin{tabular}{|c|c|c|}
\hline \multirow{2}{*}{$\begin{array}{c}\text { Zat pengatur tumbuh } \\
(\mathrm{ZPT})\end{array}$} & \multicolumn{2}{|c|}{ Peubah } \\
\hline & Panjang akar (cm) & Jumlah Akar \\
\hline Bawang merah & $3.29 \mathrm{ab}$ & $23.33 \quad \mathrm{a}$ \\
\hline Air kelapa & $2.64 \mathrm{~b}$ & $13.61 \mathrm{~b}$ \\
\hline Rootone-F & $3.63 \mathrm{a}$ & $26.17 \quad \mathrm{a}$ \\
\hline
\end{tabular}

Keterangan : Angka-angka yang diikuti oleh huruf yang sama pada kolom yang sama, tidak berbeda nyata pada taraf uji $5 \%$ (DMRT).

Tabel 4. Interaksi asal bahan stek dan Zat Pengatur Tumbuh (ZPT) terhadap peubah jumlah akar stek lidah mertua

\begin{tabular}{lrlclll}
\hline \multirow{2}{*}{ Asal Bahan Stek } & \multicolumn{7}{c}{ Zat Pengatur Tumbuh (ZPT) } \\
\cline { 2 - 7 } & \multicolumn{7}{c}{ Bawang Merah } & Air Kelapa & Rootone-F \\
\hline Bagian Atas & 30.83 & $\mathrm{Aa}$ & 15.33 & $\mathrm{ABa}$ & 27.33 & $\mathrm{Aa}$ \\
Bagian Tengah & 26.83 & $\mathrm{Ab}$ & 19.17 & $\mathrm{Ab}$ & 43.17 & $\mathrm{Aa}$ \\
Bagian Bawah & 12.33 & $\mathrm{Ba}$ & 6.33 & $\mathrm{Ba}$ & 8.00 & $\mathrm{Ba}$ \\
\hline
\end{tabular}

Keterangan: Angka yang diikuti huruf besar pada kolom yang sama dan huruf kecil pada baris yang sama menunjukkan hasil yang tidak berbeda nyata berdasarkan DMRT pada $\alpha=5 \%$. 

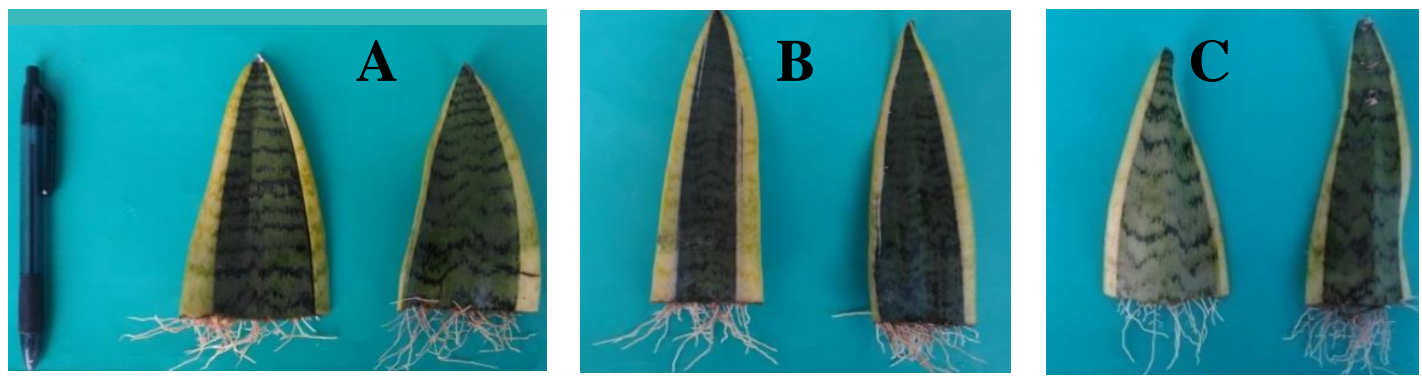

$\mathrm{A}=$ Perlakuan bawang merah, $\mathrm{B}=$ Perlakuan air kelapa, $\mathrm{C}=$ Perlakuan Rootone-F

Gambar 1. Keragaan akar pada stek daun asal bahan stek daun bagian atas
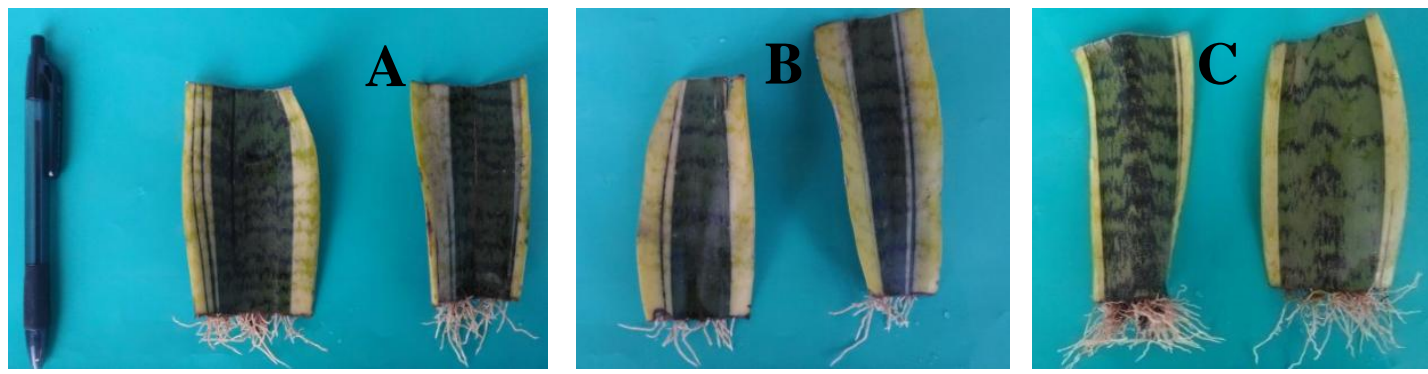

$\mathrm{A}=$ Perlakuan bawang merah, $\mathrm{B}=$ Perlakuan air kelapa, $\mathrm{C}=$ Perlakuan Rootone-F

Gambar 2. Keragaan akar pada stek daun asal bahan stek daun bagian tengah
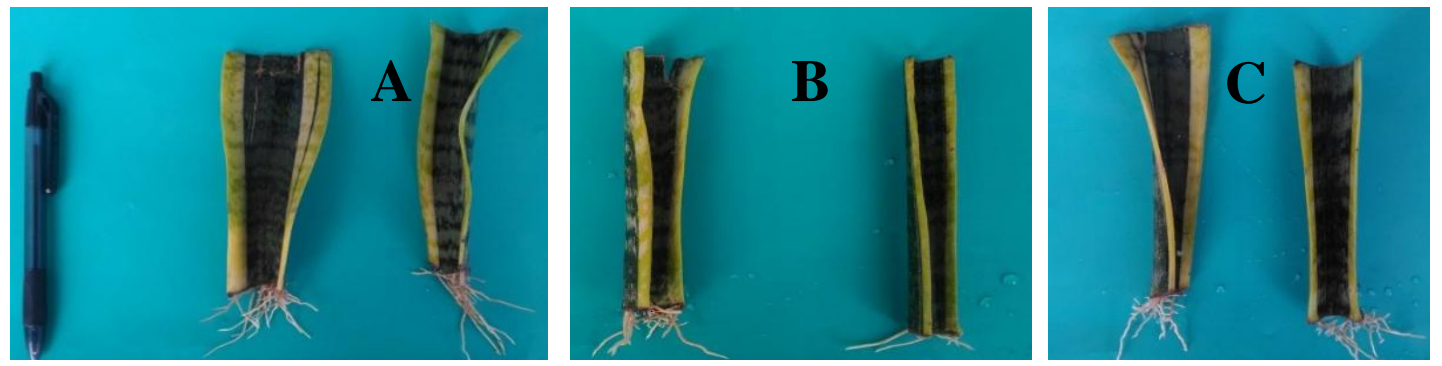

$\mathrm{A}=$ Perlakuan bawang merah, $\mathrm{B}=$ Perlakuan air kelapa, $\mathrm{C}=$ Perlakuan Rootone-F

Gambar 3. Keragaan akar pada stek daun asal bahan stek daun bagian bawah/pangkal

Auksin mempunyai peranan yang sangat penting dalam proses pertumbuhan dan perkembangan tumbuhan. Auxin disintesis di daerah meristematik terletak di pucuk kemudian diangkut ke ujung akar pada tanaman (Blakesle et.al, 2005). Zat pengatur tumbuh Rootone-F, Indole Acetic Acid (IAA) berperan di dalam mempercepat pemanjangan sel-sel pada jaringan meristem akar tanaman. Indole Butyric Acid (IBA) dan Napthalene Acetamida (NAA) pada zat pengatur tumbuh Rootone-F mempunyai peran yang sangat penting dalam pembentukan akar. Hasil penelitian Ghasemi (2012) menunjukkan bahwa pemberian IBA dan NAA (kelompok hormon auksin) meningkatkan jumlah akar dan panjang akar 
pada eksplan tanaman bunga Africa violets (Saintpaulia lonantha).

Sitokinin adalah kelas pitohormones yang mengerahkan berbagai peran dalam berbagai aspek pertumbuhan tanaman dan pengembangan, misalnya, pembelahan sel, pembentukan dan aktivitas meristem tunas, induksi ekspresi gen fotosintesis, daun penuaan, mobilisasi nutrisi, perkecambahan biji, pertumbuhan akar dan respon stres (Haberer dan Kieber, 2002).

\section{Bobot Basah Akar dan Bobot Kering Akar}

Tabel 5 terlihat bahwa asal bahan stek bagian tengah memiliki bobot basah akar tertinggi dan berbeda nyata dengan asal bahan stek bagian atas dan bawah. Bobot kering akar tertinggi terdapat pada asal bahan stek bagian tengah dan tidak berbeda nyata dengan asal bahan stek bagian atas. Asal bahan stek bagian tengah memberikan nilai bobot basah akar dan bobot kering akar tertinggi masing-masing sebesar $0.85 \mathrm{~g}$ dan $0.68 \mathrm{~g}$. Bagian daun atau

Tabel 5. Pengaruh asal bahan stek terhadap peubah bobot basah akar dan bobot kering akar

\begin{tabular}{|c|c|c|}
\hline \multirow{2}{*}{ Asal Bahan Stek } & \multicolumn{2}{|c|}{ Peubah } \\
\hline & Bobot Basah Akar (g) & Bobot Kering Akar (g) \\
\hline Bagian Atas & $0.77 \quad b$ & $0.67 \quad \mathrm{a}$ \\
\hline Bagian Tengah & $0.85 \mathrm{c}$ & $0.68 \mathrm{a}$ \\
\hline Bagian Bawah & $0.72 \mathrm{a}$ & $0.64 \mathrm{~b}$ \\
\hline
\end{tabular}

Keterangan: Angka-angka yang diikuti oleh huruf yang sama pada kolom yang sama, tidak berbeda nyata pada taraf uji $5 \%$ (DMRT).

Tabel 6. Pengaruh Zat Pengatur Tumbuh (ZPT) terhadap peubah bobot basah akar dan bobot kering akar

\begin{tabular}{|c|c|c|}
\hline \multirow{2}{*}{$\begin{array}{c}\text { Zat Pengatur } \\
\text { Tumbuh (ZPT) }\end{array}$} & \multicolumn{2}{|c|}{ Peubah } \\
\hline & Bobot basah akar (g) & Bobot kering akar (g) \\
\hline Bawang merah & 0.77 a & 0.66 a \\
\hline Air kelapa & 0.74 a & $0.64 \mathrm{~b}$ \\
\hline Rootone-F & $0.84 \quad b$ & $0.68 \quad \mathrm{a}$ \\
\hline
\end{tabular}

Keterangan : Angka-angka yang diikuti oleh huruf yang sama pada kolom yang sama, tidak berbeda nyata pada taraf uji $5 \%$ (DMRT).

Tabel 7. Interaksi asal bahan stek dan Zat Pengatur Tumbuh (ZPT) terhadap peubah bobot basah akar stek lidah mertua

\begin{tabular}{lcccccc}
\hline \multirow{2}{*}{ Asal Bahan Stek } & \multicolumn{7}{c}{ Zat Pengatur Tumbuh (ZPT) } \\
\cline { 2 - 7 } & \multicolumn{7}{c}{ Bawang Merah } & Air Kelapa & Rootone-F \\
\hline Bagian Atas & 0.78 & $\mathrm{Aa}$ & 0.74 & $\mathrm{ABa}$ & 0.80 & $\mathrm{Ba}$ \\
Bagian Tengah & 0.79 & $\mathrm{Ab}$ & 0.77 & $\mathrm{Ab}$ & 1.00 & $\mathrm{Aa}$ \\
Bagian Bawah & 0.73 & $\mathrm{Aa}$ & 0.71 & $\mathrm{Ba}$ & 0.72 & $\mathrm{Ba}$ \\
\hline
\end{tabular}

Keterangan: Angka yang diikuti huruf besar pada kolom yang sama dan huruf kecil pada baris yang sama menunjukkan hasil yang tidak berbeda nyata berdasarkan DMRT pada $\alpha=5 \%$. 
asal bahan stek yang terbaik untuk stek daun lidah mertua (Sansevieria parva) adalah bagian tengah (Sulistiana, 2013). Bobot basah dan bobot kering merupakan hasil akumulasi fotosintesis tumbuhan selama pertumbuhannya (Levitt, 1980).

Tabel 6 terlihat bahwa pemberian ZPT Rootone-F menghasilkan bobot basah akar dan bobot kering akar tertinggi. Bobot basah akar tertinggi yaitu $0.84 \mathrm{~g}$, berbeda nyata dengan ZPT bawang merah dan air kelapa. Bobot kering akar tertinggi yaitu $0.68 \mathrm{~g}$, tidak berbeda nyata dengan ZPT bawang merah tetapi berbeda nyata dengan ZPT air kelapa. Air kelapa mengandung zat pengatur tumbuh auxin, gibberelin dan sitokinin (Yong et.al, 2009). Auxin dapat merangsang pembentukan akar terutama pada perbanyakan tanaman dengan menggunakan stek (Taiz dan Zeiger, 2002).

Tabel 7 terlihat bahwa asal bahan stek bagian tengah dengan pemberian ZPT RootoneF memberikan bobot basah akar tertinggi yaitu $1.00 \mathrm{~g}$, berbeda nyata dengan asal bahan stek atas dan bawah. Bobot basah akar pada asal bahan stek bagian tengah dengan pemberian ZPT Rootone-F berbeda nyata dengan pemberian ZPT bawang merah dan air kelapa. Rootone-F merupakan zat pengatur tumbuh sintetik yang mengandung hormon auksin, gibberelin dan sitokinin. Auksin dan sitokinin merupakan hormon yang saling mendukung dalam proses pembelahan sel, terutama dalam pembentukan dan pertumbuhan akar (Taiz dan Zeiger, 2002). Rootone-F mempunyai peran yang sangat penting dalam pembentukan akar.
Penelitian Sulistiana (2013), perlakuan kombinasi ZPT sintetik (Rootone-F) dengan asal bahan stek bagian tengah memberikan hasil yang terbaik pada parameter bobot basah akar dan bobot kering akar stek daun tanaman Sansevieria parva.

\section{SIMPULAN}

Hasil penelitian menunjukkan bahwa asal bahan stek dan Zat Pengatur Tumbuh (ZPT) berpengaruh terhadap panjang akar, jumlah akar, bobot basah akar dan bobot kering akar. Interaksi terdapat pada peubah jumlah akar dan bobot kering akar. Asal bahan stek bagian tengah dengan pemberian ZPT Rootone-F memberikan jumlah akar terbanyak yaitu 43.17 dan bobot basah akar tertinggi yaitu $1.00 \mathrm{~g}$.

\section{DAFTAR PUSTAKA}

Adita BRC, Ratni NJ, Naniek AR. 2011. Kemampuan Penyerapan Tanaman Hias dalam Menurunkan Polutan Karbon Monoksida. Jurnal Ilmiah Teknik Lingkungan. 4(1): 54-60.

Alam S, Han KD, Lee JM, Hur H, Shim JO, Chang KC, Lee TS, Lee MW. 2004. In vitro effects of plant extracts and phytohormones on Mycelial Growth of Anthracnose Fungi. Mycobiologi. 3 (23): 134-138

Blakeslee JJ, Peer WA, Murphy AS. 2005. Auxin transport. Curr. Opin. Plant Bio. 8: 494-500.

Davies PJ. 2010. The Plant Hormones: Their Nature, Occurrence, and Functions Department of Plant Biology. DOI: 10.1007/978-1-4020-2686-7_1 https://www.researchgate.net/publication/ 
225216023The Plant Hormones Their Nature_Occurrence_and_Functions

Ghasemi Y. Nematzadeh GA, Omran VG, Dehestani A, Hosseini S. 2012. The effects of explant type and phytohormones on African violet (Saintpaulia ionantha) micropropagation efficiency. Biharean Biologist. 6 (2): $73-$ 76 Article No:121109 http://biozoojournals.3x.ro/bihbiol/index. html

Haberer G, Kieber JJ. 2002. Cytokinins. New insights into a classic phytohormone. Plant Physiol.128: 354-362.

Jean WH, Yong, Ge L, Fei YN and Tan SN. 2009. The Chemical Composition and Biological Properties of Coconut (Cocos nucifera L.) Water. Molecules. 14: 51445164; doi:10.3390/molecules 14125144

Djamhuri E. 2011. Pemanfaatan Air Kelapa untuk Meningkatkan Pertumbuhan Stek Pucuk Meranti Tembaga (Shorea leprosula Miq.). J. Silvikultur Tropika. 2(1): 5-8.

Kende H, Zeevaart JAD. 1997. The Five "Classical" Plant Hormones. The Plant Cell. 9 (1): 197-121

Levitt J. 1980. Responses of Plants to Environmental Stresses. Ed ke-2. NewYork (US): Academic Pr.

Lombogia B, Budiarso F, Bodhi W. 2016. Uji daya hambat ekstrak daun lidah mertua (Sansevieriae trifasciata folium) terhadap pertumbuhan bakteri Escherichia coli dan Streptococcus sp. Jurnal e-Biomedik $(e B m) .4(1)$

Marpaung AE, Hutabarat RC. 2015. Respon Jenis Perangsang Tumbuh Berbahan Alami dan Asal Setek Batang Terhadap Pertumbuhan Bibit Tin (Ficus carica L.) (The Response of Natural Growing Stimulant Materials and Stem Cutting Origin to the Growth of Fig Seedling). J. Hort. 25(1): 37-43
Mayasari E, Budipramana LS, Rahayu YS. 2012. Pengaruh Pemberian Filtrat Bawang Merah dengan Berbagai Konsentrasi dan Rootone-F terhadap Pertumbuhan Stek Batang Tanaman Jambu Biji (Psidium guajava L.) Lentera Bio. 1 (2): 99-103

Marfirani M., Rahayu Y dan Ratnasari E. 2014. Pengaruh Pemberian Berbagai Konsentrasi Filtrat Umbi Bawang Merah dan Rootone-F terhadap Pertumbuhan Stek Melati "Rato Ebu": Effect of Various Concentration of Onion Filtrate and Rootone-F on the "Rato Ebu" Cuttings Jasmine Growth. http://ejournal.unesa.ac.id/index.php/lent erabio. Lentera Bio. 3 (1): 73-76

NASA. 1989. Interior Landscape Plant for Indoor Air Pollution Abatement. https://ntrs.nasa.gov/archive/nasa/casi.ntr s.nasa.gov/19930073077.pdf

Sulistiana S. 2013. Respon pertumbuhan stek daun lidah mertua (Sansevieria parva) pada pemberian zat pengatur tumbuh sintetik (Rootone-F) dan asal bahan stek. Jurnal Matematika, Sains dan Teknologi. 14(2): 107-118

Taiz L, Zeiger E. 2002. Plant Physiology. Third Edition. Massachussetts (US): Sinaue Associaties Inc. Publisher.

Tan SN, Yong JWH, Ge L. 2014. Analyses of Phytohormones in Coconut (Cocos nucifera L.) Water Using Capillary Electrophoresis-Tandem Mass Spectrometry. Chromatography. 1: 211226; doi:10.3390/chromatography 1040211. 